\title{
Editorial
}

\section{Trilhando Novos Caminhos}

Com este número, PSICOLOGIA EM PESQUISA encerra mais um ano de atividades, trazendo três novidades. Primeiro, a indexação em uma nova base de dados (Lilacs). Segundo, a publicação de dez artigos em cada número, além da seçáo livre e da resenha. Finalmente, a produção da revista começa agora a ser responsabilidade da Zeppelini Editorial, uma empresa altamente especializada na publicação de periódicos científicos. Com isso, acreditamos estar trilhando novos caminhos rumo a um aumento da representatividade, da qualidade e do alcance do periódico.

Assim como nas ediçóes anteriores, este número traz contribuições de várias áreas do conhecimento psicológico, respeitando a diversidade temática e metodológica característica da área.

No primeiro artigo, Mendonça, Coelho e Júca apresentam os resultados empíricos de um estudo correlacional sobrea síndrome de burnoutem professores/ médicos de instituiçóes públicas em Alagoas. Os autores enfatizam o papel negativo do estresse e chamam a atenção para a necessidade de intervenção e mais estudos voltados a essa população.

Ainda no plano das pesquisas empíricas, Rueda e Castro realizam um estudo sobre validade para o Teste de Inteligência (TI), comparando-o com outros dois testes. Os resultados indicam coeficientes de correlação moderados e positivos (acima de 0,509), bem como correlaçóes variando entre 0,20 e 0,50 , garantindo a validade pela comparação com testes que avaliam construtos relacionados.

Em seguida, Freitas e Oliveira analisam os impactos psicossociais da relação entre educação e profissionalização na ótica de jovens participantes de um Programa de Aprendizagem (PA), no estado do Paraná. Os resultados mostram a influência dos amigos e colegas de trabalho e a importância da qualificaçáo para o ingresso e permanência no posto de trabalho. Ao final, as autoras fazem uma reflexão sobre o papel da educação profissionalizante na juventude.

No quarto artigo, Justi e Justi investigam o efeito da similaridade ortográfica no reconhecimento de letras em uma tarefa de Reicher-Wheeler. Os resultados mostram que as letras das pseudopalavras que tinham muitos vizinhos ortográficos foram reconhecidas com maior precisão do que as letras das pseudopalavras que não tinham vizinhos ortográficos. Os autores encerram o trabalho apresentando uma explicação para o efeito encontrado.

A seguir, Costa et al. fazem uma análise da produção científica sobre a formação de psicólogos no Brasil.
Os resultados principais sugerem que a produção sobre a temática encontra-se dispersa e apresenta caráter opinativo. Os autores ressaltam ao final a necessidade de mais articulaçáo entre os pesquisadores do campo e de maior produção de estudos sobre o tema.

Em outro estudo de revisão, Haase et al. discutem os possíveis mecanismos cognitivos envolvidos nas Dificuldades de Aprendizagem da Matemática (DAM). Os autores apontam que o processamento fonológico, a memória de trabalho, o processamento visoespacial e o senso numérico são domínios potencialmente subjacentes às DAM, mas salientam a necessidade de mais estudos.

Ainda no campo dos estudos de revisão, Silva, Rodrigues e Silveira analisam as possíveis relaçóes entre o desenvolvimento social e a compreensão dos estados mentais, como desejo, crenças e emoçóes. As relaçôes de amizade, o comportamento pró-social, a empatia e a aceitação social são destacados como fatores fundamentais nesse processo.

Entrando no plano dos debates teóricos, Silva discute uma possível nova abordagem de prediçáo de estados emocionais a partir da perspectiva da Teoria do Apego. Centrando sua análise na psicologia do esporte, apresenta a identificação dos estilos de apego de atletas como forma de predizer as tendências de seus comportamentos nos períodos pré, durante e pós-competição.

No penúltimo artigo, Ambiel e Noronha discutem o construto autoeficácia para escolha profissional, a partir da Teoria Social Cognitiva (TSC) e sua aplicação ao contexto das decisóes de carreira. Eles concluem que o construto, embora carente de maior divulgaçáo no Brasil, tem obtido espaço no meio científico nacional e pode se constituir como uma importante ferramenta de compreensão, planejamento e avaliação do processo de escolha profissional.

Encerrando a seção de artigos, Rooke e Pereira-Silva analisam a produção científica na área de resiliência familiar nos últimos 21 anos. Os resultados apontam para a necessidade de ampliar os estudos sobre o assunto, utilizando maior número de participantes e instrumentos/técnicas combinados para a coleta de dados.

Para encerrar este número de PSICOLOGIA EM PESQUISA, temos uma entrevista especial com o Professor Horst Gundlach e uma resenha do livro "Memória", escrito por Iván Izquierdo.

Saulo de Freitas Araujo 